determining the direction in which a great nation shall seek deliverance from the thraldom of ignorance and tradition. Nowhere in the world is there such a field for the best class of medical missionary as in China, and where else is there such a movement for the emancipation of woman? It is not possible to write of the new pathological problems to be solved in China, for they are not yet known, but they must be many and of great importance. Anthropology, zoology, botany offer rich fields for hobbies or collateral study. And all is to be done in a land of many and great natural beauties, among a people with a civilisation far older than any in Europe, and an unequalled reverence for their great literature and exquisite art.

Many of your readers must remember the martyrs of the Boxer rising and the effort to expel foreigners from China, yet already we have the magnificent Rockefeller Medical College at Peking, the great Christian University at Tsinanfu, the splendid institutions of Dr. and Mrs. Duncan Main at Kangchow, the unique institution of Mr. Whiteright at Tsinanfu, and many another similar good work. Readers of Miss E. G. Kemp's " Chinese Mettle " will know how urgent is the need for well-trained, sympathetic, open-minded Christian men and women to aid the Chinese in the development of what promises to be the greatest and most eventful social evolution of history. Our countrymen have ever been foremost in high adventure, and it is to be hoped that British medical men and women will take their full share in making and moulding a new China.

I am, Sir, yours faithfully,

London, Feb. 15th, 1922. ALFRED PeARCE Gould.

\section{ALPINE TREATMENT OF TUBERCULOSIS.}

\section{To the Editor of THE LANCET.}

SIR,-I cannot agree with your correspondent, Sir Martin Conway (The LANCET, Feb. 11th), that "the passport tyrants in all Foreign Offices and Consulates and other interferences with free international travel resulting from the war, have had a disastrous effect upon the treatment of tuberculosis." It seems difficult to say on what grounds and for what purpose he makes this sweeping and not too generous statement. The alpine resorts for the treatment of pulmonary tuberculosis are very much overratedand a]so very much advertised. Egypt, the Canary Islands, and South Africa have had their day. Now it is Switzerland.

The medical profession have had an opportunity of testing the results of treatment in our "damp and sunless" climate during the last 25 years or more, and I venture to say that a good many of us are satisfied that results as satisfactory can be obtained in British sanatoriums. If Sir Martin Conway will compare the results of treatment in some of our leading sanatoriums with those of similar institutions in Switzerland, he could satisfy himself on this point. We hear about the wonderful cures from Switzerland. We hear little or nothing about the failures. Here are two of them. A medical man went to Davos in 1910, suffering from extensive tuberculosis of the lung:s with raised temperature and numerous tubercle bacilli in his sputum. While there he lost weight, developed a tuberculous laryngitis, and was sent home by one of the English physicians. On arrival in England, he went into a small private sanatorium, and nine months later he was sufficiently recovered to take up a public appointment. $\mathrm{He}$ is to-day in perfect health, is married, and has two healthy children. Another patient had spent two winters in an English sanatorium in Davos and was sent back to die in the spring of 1911. When he reached his home in a London suburb, he built a hut in his back garden and underwent the cure there. I had a letter from him the other day and apparently he is very well now.

The Swiss climate is certainly ideal for the sun cure in surgical tuberculosis, but it is not always the ideal climate for pulmonary tuberculosis as these two cases show. Before the war, the Queen Alexandra Sanatorium and other similar institutions in Switzerland found it difficult to carry on, chiefly because few patients cared to spend the summer months there, when the climate is, if anything, worse than ours. These institutions were running at a loss because patients did not find it "disastrous" to spend the summer months in British sanatoriums.

The class of patient for which Sir Martin Conway is appealing would, I venture to say, do just as well under treatment in a sanatorium in this country. They do not belong to the idle rich who can afford to go to Switzerland winter after winter. Most of them have to earn their livings. For them to undergo the cure in the same climate in which they are going to live and work is preferable. I believe this is the vjew held by many experts in this and other countries.

I am, Sir, yours faithfully, Felrx Savy, M.B., Ch.B.

Grampian Sanatorium, Kingussie, lnverness-shire, Feb. 16th, 1922 .

\section{THE EDUCATION OF THE DEAF.}

\section{To the Editor of THE LANCET.}

SIR,-In support of Mr. Macleod Yearsley's letter under this heading in your issue of Feb. 11th I would advance the following arguments.

1. Deaf children are now taken into the Scottish schools and institutions at the age of 5 and into the schools of the Glasgow educational authority at the age of 3. Why should an English child be handicapped by having to wait till he is 7 years old ?

2. One may argue quite fairly that a hearing child from a decent home may delay his entrance to school by a year and find himself at 14 or 16 years not a bit behind, because during the year at home his education has been progressing and his mind developing, but the deaf child's mind does not begin to develop till he enters school.

As one who has worked for the deaf for over 30 years, and who has been a steady advocate for the early commencement of their education, I should deplore any step which would delay that commencement.-I am, Sir, yours taithfully,

JAMES KerR Lovf, M.D., F.R.F.P.S.G.

Glasgow, Feb. 20th, 1922.

\section{AMAAS OR ALASTRIM?}

\section{To the Editor of THE LANCET.}

SIR,--In your issue of Dec. 17th, 1921, you annotate a paper by Dr. W. G. MacCallum and Dr. L. M. Moody on Alastrim, which appeared in the American Journal of Hygiene. I saw a great number of such cases when surgeon-major to the Cape Mounted Rifles in 1876-77-78 during the Gaika and Galeka wars. The disease has been known and prevalent amongst the native races from time immemorial, and known as" amaas." Thousands of men, women, and children prisoners were affected, but their condition gave rise to no concern. I still meet with cases in the Kaffir kraals and Native Affairs Department. To experienced South African medical men it is easily recognised. I have never seen a case in the white race.

It is but just that Dr. de Korte should be given the credit of having made the first careful study and published a paper on Amaas, or Kaffir Milk-Pox, which appeared in your columns on May 7 th, 1904. In July, 1911, Dr. Emilio Ribas, of São Paulo, Brazil, published in the Transactions of the Society of Tropical Medicine and Hygiene a paper entitled Alastrim, Amaas, or Milk-Pox, stating his opinion that the disease he was writing of was probably amaas as described by Dr. de Korte. Therefore, according to the rules of nomenclature, the name should be "amaas" and not " alastrim."

I am, Sir, yours faithfully,

Benoni, Transvaal, Jan. 23rd, 1922. J. FEHRSEN, M.D. 